https://doi.org/10.15407/ujpe65.8.662

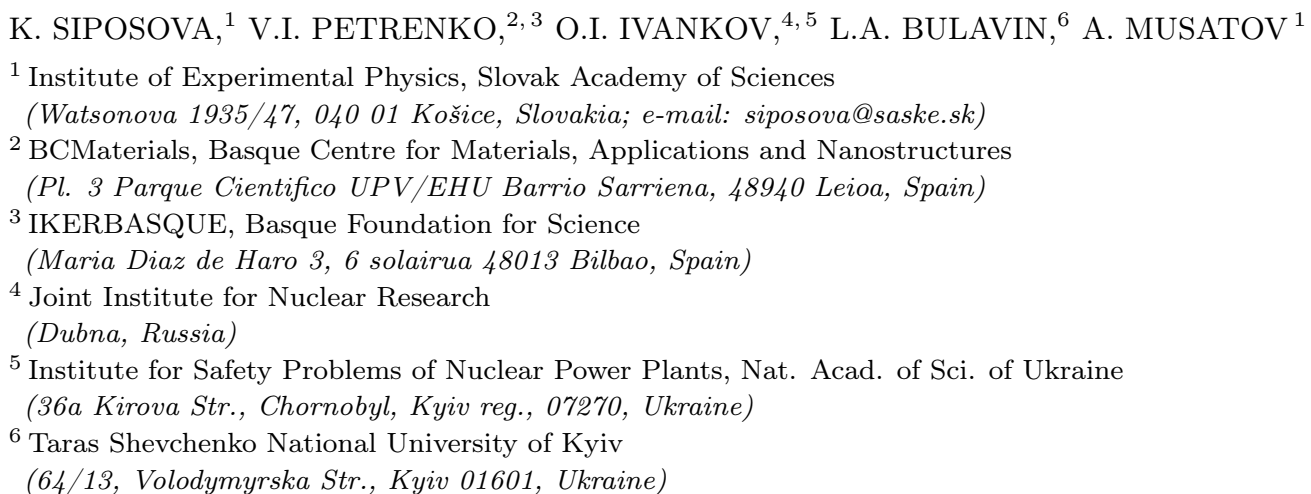

\title{
SMALL-ANGLE NEUTRON SCATTERING STUDY OF BICELLES AND PROTEOBICELLES WITH INCORPORATED MITOCHONDRIAL CYTOCHROME c OXIDASE
}

\begin{abstract}
The structural investigations of a model membrane system, bicelles, and the aggregation state of isolated and purified bovine heart cytochrome c oxidase $(\mathrm{CcO})$ in bicelles have been performed using small-angle neutron scattering (SANS), SANS contrast variation, and complemented by various biophysical and biochemical techniques. The average size of bicelles prepared from long-chain 1,2-dimyristoyl-sn-glycero-3-phosphocholine and short-chain 1,2dihexanoyl-sn-glycero-3-phosphocholine was found to be about $22 \mathrm{~nm}$ with a thickness of about $4 \mathrm{~nm}$. Enzyme in bicelles was remained active and structurally unaltered. The estimated volume of protein in bicelles of $240 \mathrm{~nm}^{3}$ corresponded well to the monomeric form of $\mathrm{CcO}$. The ab initio modeling supports the experimental data and suggests that $\mathrm{CcO}$ in bicelles is a homogeneous monomeric complex incorporated into bicelles.
\end{abstract}

Ke ywords: small-angle neutron scattering, bicelles, cytochrome c oxidase, aggregation state.

\section{Introduction}

Cytochrome c oxidase (EC 1.9.3.1; Complex IV; $\mathrm{CcO})$ is a large transmembrane electron transfer complex found in bacteria and mitochondria of eukaryotes. Mitochondrial $\mathrm{CcO}$ is a protein-phospholipid complex consisting of 13 dissimilar protein subunits with a combined molecular weight of $\approx 205000 \mathrm{Da}$ for monomeric $\mathrm{CcO}$ [1]. However, only two subunits contain the redox-active centers. Two hemes, heme $a$ and heme $a_{3}$, and two copper centers, $\mathrm{CuA}$ and $\mathrm{CuB}$, are located in subunits I and II. In addition, $\mathrm{CcO}$ also contains a certain amount of protein-bound phospholipids. The enzyme catalyzes the transfer of electrons from ferrocytochrome $\mathrm{c}$ to oxygen, a reac-

(C) K. SIPOSOVA, V.I. PETRENKO, O.I. IVANKOV, L.A. BULAVIN, A. MUSATOV, 2020 tion coupled to the proton translocation across the inner mitochondrial membrane [2]. $\mathrm{CcO}$, being isolated, purified, and crystalized in the presence of sodium cholate, is clearly dimeric within three-dimensional crystals [3]. However, the self-association of isolated and detergent-solubilized enzyme is more complicated and strongly depends upon a full complement of subunits, the presence of bound cardiolipin, and last, but not least the type and concentration of a detergent $[4,5,6]$. Moreover, the detergent-induced monomerization/dimerization is a reversible process. Therefore, the homogeneous dimeric or monomeric state of $\mathrm{CcO}$ is difficult to maintain. A somewhat different approach to investigate structural and functional properties of the membrane proteins is to use the membrane model systems, including vesicles, supported bilayers, nanodisks, and bi-

ISSN 2071-0194. Ukr. J. Phys. 2020. Vol. 65, No. 8 
celles. Bicelles represent an attractive membrane-like structure widely used as model membranes in biological studies. Structurally, bicelles can be thought of as lipid bilayer disks that are formed by the addition of a short-chain lipid or detergent (such as zwitterionic bile salt derivative CHAPS or CHAPSO) to a long-chain lipid in an aqueous medium (Fig. 1). In our previous work, $\mathrm{CcO}$ isolated from bovine heart was successfully incorporated into bicelles which were formed from 1,2-dimyristoyl-sn-glycero-3-phosphocholine, (DMPC) and 1,2-dihexanoyl-sn-glycero-3-phosphocholine, (DHPC) [7]. The bicelles and $\mathrm{CcO}$ incorporated into bicelles ("proteobicelles") were characterized by absorption spectroscopy, dynamic light scattering (DLS), atomic force microscopy (AFM), sedimentation velocity, and differential scanning calorimetry. It was demonstrated that, at the total concentration of phospholipids CL $=24 \mathrm{mM}$ and the molar ratio " $q$ " of long-chain DMPC over shortchain DHPC equal to 0.5 , the thickness of analyzed individual bicelles was very similar within an entire population and found to be $4 \pm 1 \mathrm{~nm}$. However, the size of bicelles, measured by DLS and AFM, varied from 10 to $50 \mathrm{~nm}$. On the other hand, adding $\mathrm{CcO}$ to bicelles generated only one single DLS peak suggesting that the main fraction of $\mathrm{CcO}$ in bicelles was uniform having a well-defined size. It was concluded that the insertion of $\mathrm{CcO}$ to bicelles of different sizes resulted in the size unification of "proteobicelles". It was also concluded that $\mathrm{CcO}$ in bicelles is monomeric [7]. In the present work, we will focus on the structural investigation of bicelles and complexes of bicelles with CcO. Structural information about such systems and formed complexes was obtained using the small-angle neutron scattering (SANS) technique and complemented by atomic-force microscopy and dynamic light scattering. It is well known that SANS is well suitable for the nanoscale structural characterization and has proven itself in structural studies of various complex nanosystems [8, 9]. In addition, the SANS contrast variation technique was successfully used to detail a structural characterization of some complexes with bio-macromolecules and to obtain information about the volume fractions of components in a two-component object [10]. It should be also mentioned that the combination of SANS and AFM was used previously for a detailed structural characterization of specific protein aggregates [11]. Thus, in the present work, SANS, SANS con- trast variation, and $a b$ initio modeling in combination with various biochemical and biophysical methods have been applied to investigate bicelles and multicomponent complexes of bicelles with incorporated cytochrome c oxidase.

\section{Materials and Methods}

\subsection{Materials}

Both, 1,2-dihexanoyl-sn-glycero-3-phosphocholine (DHPC) and 1,2-dimyristoyl-sn-glycero-3-phosphocholine (DMPC) in chloroform were obtained from Avanti Polar Lipids, Inc. (Alabaster, AL, USA). Sodium cyanide, sodium dithionite, and Triton X-100 (TX-100, T8787) were purchased from Sigma-Aldrich Corporation (St. Louis, MO; USA). n-Dodecyl $\beta$ D-maltoside was obtained from Anatrace Products LLC. All other chemicals were reagent grade.

\subsection{Methods}

Cytochrome c oxidase was isolated from freshly frozen beef heart by the method of Fowler et al. [12] with modifications as reported by Mahapatro and Robinson [13]. Isolated enzyme was dissolved in $0.1 \mathrm{M}$ phosphate buffer ( $\mathrm{pH} 7.4$ ), containing $1.0 \%$ sodium cholate. The isolated complex contained $9 \mathrm{nmol}$ of heme $a$ per $\mathrm{mg}$ of protein. The protein concentration was measured by the Biuret method using bovine serum albumin as a standard. The concentration of the enzyme was determined from the absorption difference spectra (reduced minus oxidized) using an extinction coefficient value at $\Delta_{605-630}$ of $27 \mathrm{mM}^{-1} \mathrm{~cm}^{-1}$. The $\mathrm{CcO}$ subunit composition was verified by reversedphase HPLC as described previously [14], and the results demonstrated the presence of all nuclearencoded subunits (data not shown). The CcO activity was measured spectrophotometrically following the rate of oxidation of $30 \mu \mathrm{M}$ ferrocytochrome c by $2 \mathrm{nM}$ enzyme in $25 \mathrm{mM}$ phosphate buffer $(\mathrm{pH}$ 7.0) containing either $2 \mathrm{mM}$ dodecyl maltoside or DMPC-DHPC bicelles. Spectrophotometric measurements were performed using a Jasco V-630 spectrophotometer in $10 \mathrm{~mm}$ optical pathway cells at $25^{\circ} \mathrm{C}$. The bicellar DMPC-DHPC samples were prepared as described previously [7]. Briefly, the appropriate volume of DMPC in chloroform was dried out under a stream of nitrogen. Then the appropriate volume of DHPC was added, and the mixture was dried again. The resulting phospholipids film was dis- 


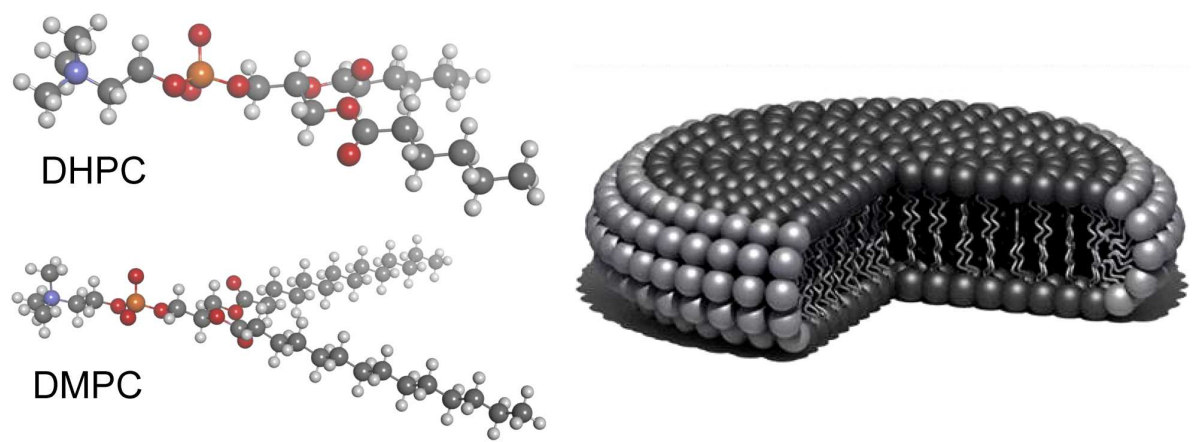

Fig. 1. 3-D beads models of DHPC and DMPC (left panel) and a schematic model of DMPC-DHPC bicelle (right panel)

solved by the brief vortexing in a buffer solution at $25{ }^{\circ} \mathrm{C}$. The hydration of phospholipids and the formation of bicelles were achieved by the incubation of phospholipids for about $3 \mathrm{~h}$ at $25{ }^{\circ} \mathrm{C}$ with an occasional vortexing (Fig. 1). The $\mathrm{CcO}$ incorporation to bicelles was accomplished by the addition of a concentrated enzyme to a final concentration of about $5 \mu \mathrm{M}$.

SANS experiments were performed at the YuMO small-angle scattering instrument at the IBR-2 pulsed reactor (JINR, Dubna, Russia) operating in the timeof-flight mode. The isotropic differential cross-section per sample volume (hereafter, referred to as the scattered intensity) was obtained with the two-detector system [15] as a function of the scattering vector module, $q$, within the $q$ interval $0.07-5 \mathrm{~nm}^{-1}$. SANS measurements were performed at $20{ }^{\circ} \mathrm{C}$ with the control by a "Lauda" liquid flow thermostat connected to a special thermobox with a sample cartridge inside. The SAS program was used for the correction of measured scattering curves for the background scattering from buffer solutions and the absolute calibration of the scattered intensity according to a special procedure using the vanadium standard [16].

The AFM imaging was performed on a scanning probe microscope (Veeco di Innova, Bruker AXS Inc., Madison, WI) working in a tapping mode. The images were recorded using antimony (n) doped Si cantilever (NCHV, Bruker AXS Inc., Madison, WI) with a spring constant of $42 \mathrm{Nm}^{-1}$ and a resonance frequency of $320 \mathrm{kHz}$. AFM images were acquired at a scan rate of $0.25-0.5 \mathrm{kHz}$ with a resolution of 512 pixels per line $(512 \times 512$ pixels/image $)$ at $25 \pm 1{ }^{\circ} \mathrm{C}$. The AFM images were analyzed using the NanoScope Analysis 1.20 software (Veeco di Innova, Bruker AXS Inc., Madison, WI, USA). No smoothing or noise re- duction was applied. Samples for the AFM visualization were prepared by the spotting of $5 \mu \mathrm{L}$ aliquots bicelles solution $(\mathrm{CL}=24 \mathrm{mM}$ ) on a freshly cleaved mica surface (highest grade V1 mica discs Ted Pella) and led to dry for $24 \mathrm{~h}$ in air at room temperature.

\section{Result and Discussion}

\subsection{Characterization of cytochrome c oxidase in bicelles}

In the present work, two relatively minor but important changes have been made in the sample preparation: (i) the time of hydration of phospholipids was increased up to 72 hours; (ii) in contrast to our previous work [7], a slow form of $\mathrm{CcO}$ (isolated and purified in sodium cholate, and reacting slowly with the external ligands) has been used.

AFM images of the bicelles were obtained by an atomic force microscope using the tapping mode. Figure 2 represents the AFM images of DMPC-DHPC bicelles with mean particle diameters of $22 \pm 3 \mathrm{~nm}$. The value is in good agreement with our DLS experimental data (not shown) and previously published data [7]. However, it should be noted that the size of bicelles can be affected by many factors, such as a ratio between long- and short-chain phospholipids, total phospholipid ratio, temperature, and absence or presence of cations. The thickness or height of bicelles was found to be $4 \pm 1 \mathrm{~nm}$, which is in good agreement with the literature data (Fig. 2).

The concentrations of DMPC and DHPC have been chosen based on the reducibility of $\mathrm{CcO}$ heme centers, and such experimental approach has been described in our previous work [7] in detail. The concentration of DMPC was $7 \mathrm{mM}$, while the concen-

ISSN 2071-0194. Ukr. J. Phys. 2020. Vol. 65, No. 8 

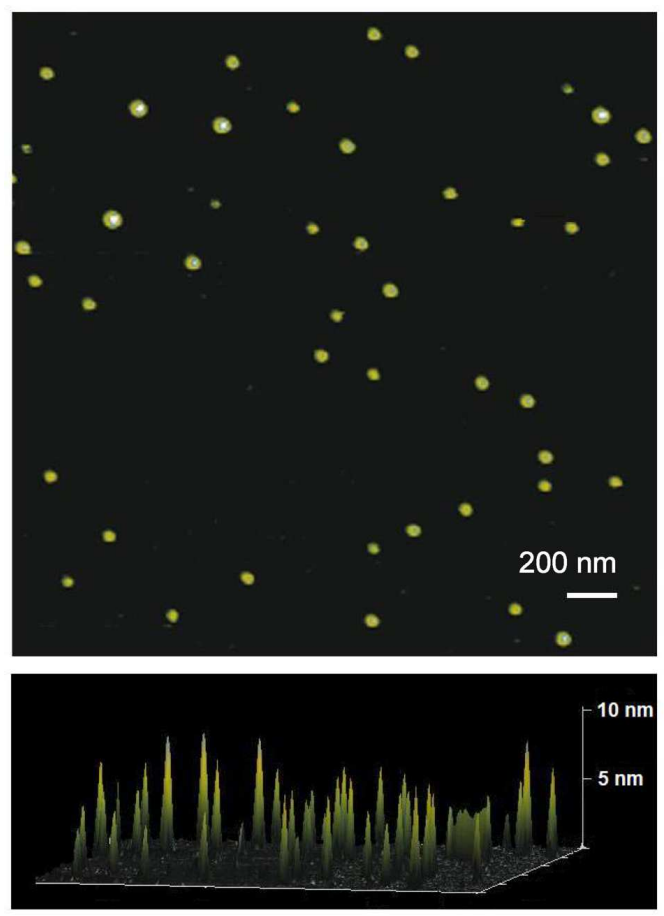

Fig. 2. AFM visualization of $24 \mathrm{mM}$ bicelles (mix of $17 \mathrm{mM}$ DHPC and $7 \mathrm{mM} \mathrm{DMPC)}$ in $20 \mathrm{mM}$ phosphate buffer, $\mathrm{pH}$ 7.4 (Upper panel) and the perpendicular view to the scanning plane image for the determination of heights (Lower panel). The $x y$ scale is $2.5 \times 2.5 \mu \mathrm{M}$. The data analysis was performed using the NanoScope Analysis 1.20 software

tration of DHPC was $17 \mathrm{mM}$. The key properties of $\mathrm{CcO}$ in bicelles are very similar to those previously reported for enzyme that was solubilized in a detergent and DMPC-DHPC bicelles [7]. The completely oxidized slow form of $\mathrm{CcO}$ in bicelles exhibits the absorption maximum at $420 \mathrm{~nm}$ and a broad band at $599 \mathrm{~nm}$ (Fig. 3). The sodium dithionite-reduced enzyme exhibited a characteristic $\alpha$-maximum at $605 \mathrm{~nm}$, a significant absorption band at $444 \mathrm{~nm}$, and a weak maximum at $517 \mathrm{~nm}$. The value of the $\mathrm{A}_{444}$ (reduced)/ $\mathrm{A}_{420}$ (oxidized) was 1.21 suggesting that heme $a$ and heme $a_{3}$ are fully reduced, and heme prosthetic groups are not perturbed by DMPCDHPC. Figure 4 shows the typical absorption spectra of $\mathrm{CcO}$ induced in the Soret region by the addition of the external ligand, $\mathrm{KCN}(100 \mu \mathrm{M})$ to the oxidized enzyme $(3 \mu \mathrm{M})$. The time course of the reaction is clearly biphasic (inset) and comprises an initial burst observed within the first $200 \mathrm{sec}$ of incubation and a slower second phase.

ISSN 2071-0194. Ukr. J. Phys. 2020. Vol. 65, No. 8

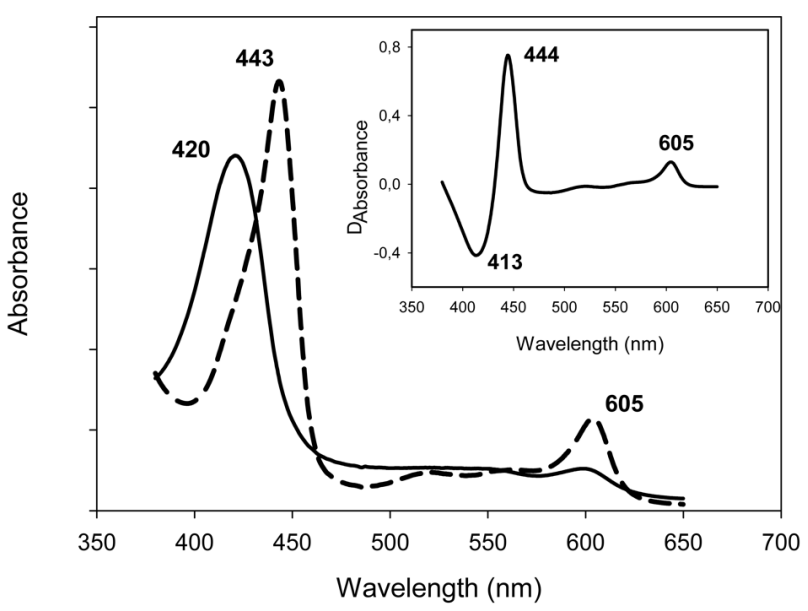

Fig. 3. Absorption spectrum of oxidized (solid line) and dithionite-reduced (dash line) cytochrome c oxidase in DMPCDHPC bicelles. Inset - difference spectrum (reduced minus oxidized). The concentration of $\mathrm{CcO}$ was $5.7 \mu \mathrm{M}$

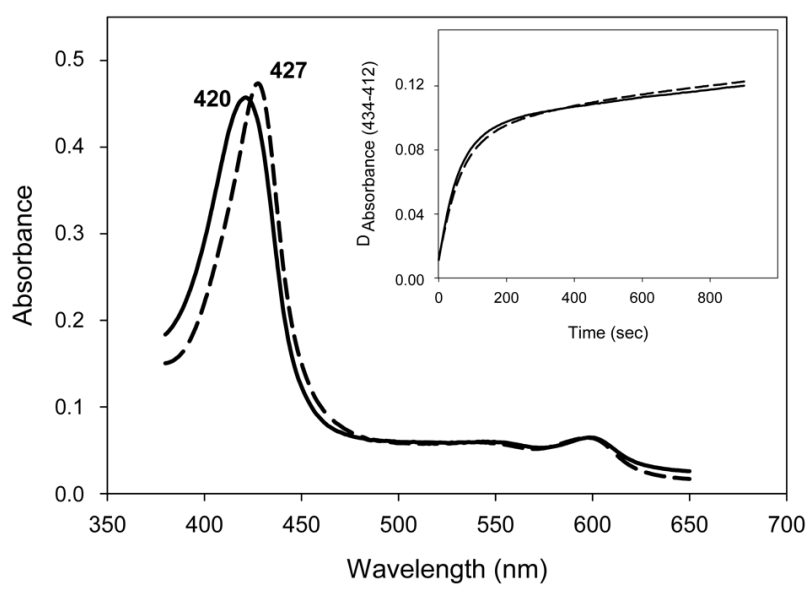

Fig. 4. Cyanide-induced spectral changes of cytochrome c oxidase in DMPC-DHPC bicelles. Inset - kinetics of cyanide binding to heme $a_{3}$. The concentrations of $\mathrm{CcO}$ and KCN were $0.3 \mu \mathrm{M}$ and $100 \mu \mathrm{M}$, respectively

Such kinetics is typical of the slow form and suggests the unaltered heme $a_{3}$ center of CcO. The activity of isolated and purified $\mathrm{CcO}$ measured in a $25 \mathrm{mM}$ phosphate buffer ( $\mathrm{pH} 7.0$ ) containing $2 \mathrm{mM}$ dodecyl maltoside was $270-280 \mathrm{~s}^{-1}$. The activity of $\mathrm{CcO}$ was significantly lower in DMPC-DHPC bicelles and was found to be $\sim 80 \mathrm{~s}^{-1}$. However, the full activity was restored, if the activity of proteobicelles $(\mathrm{CcO}$ in bicelles) was measured in dodecyl maltoside containing a buffer. Therefore, the loss of the electron transport activity of $\mathrm{CcO}$ is not due to alterations of the enzyme 


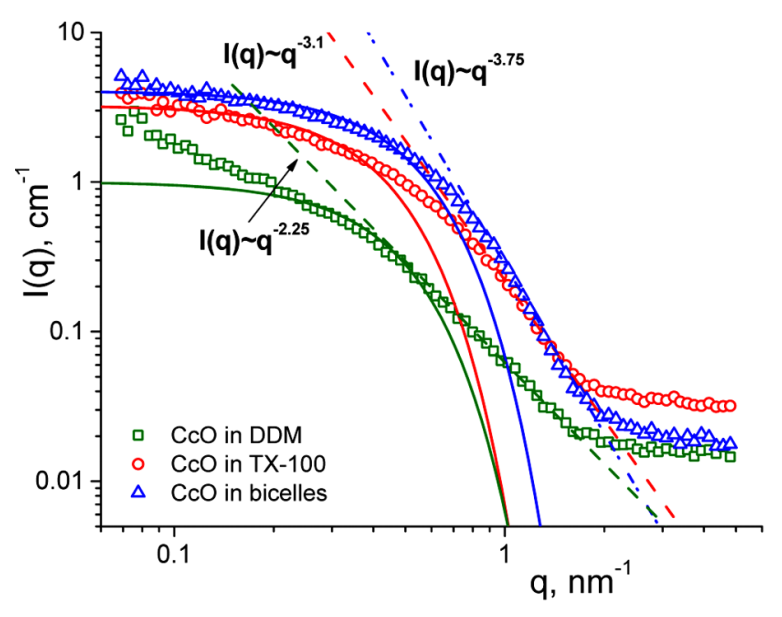

$a$

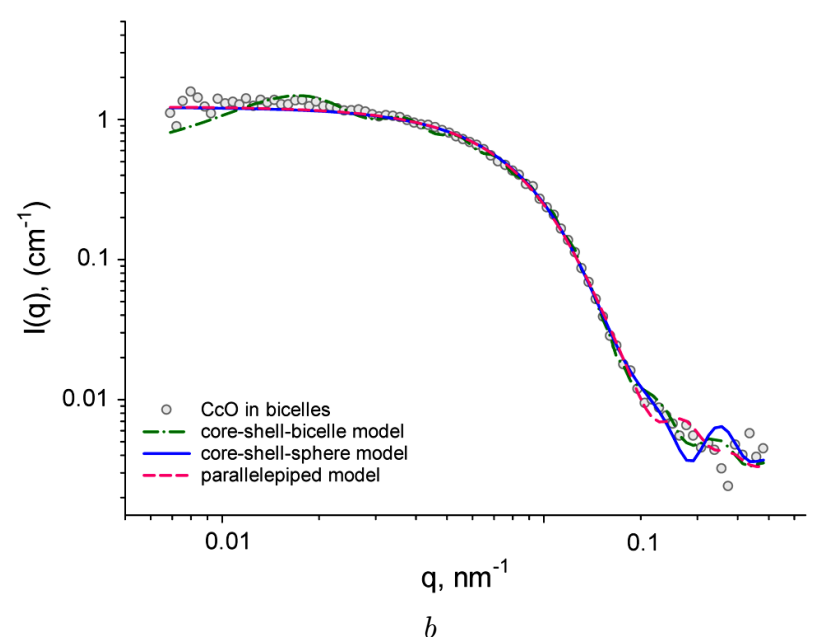

$b$

Fig. 5. Experimental SANS data of CcO incorporated into bicelles and detergent-micelles in TRIS-DCl buffer solution with power law functions $(a)$ and the experimental scattering curve of CcO incorporated into bicelles with various structural models $(b)$

in bicelles, but it is almost certainly due to the zwitterionic nature of both, DMPC and DHPC, that interfere with the electrostatic interaction between cytochrome $\mathrm{c}$ and $\mathrm{CcO}$.

\subsection{SANS evaluation of bicelles and bicelles with cytochrome c oxidase}

The SANS method is frequently used in the structural investigation of nanoscale objects in a homogeneous matrix $[8-11,17,18]$. To maximize the scattering length-density contrast, $\triangle \rho$, between particles and the matrix, deuterated water is used to prepare aqueous nanosystems. Experimental SANS data for aqueous solutions of $\mathrm{CcO}$ in detergents and bicelles are presented in Fig. 5, a. The SANS curves were fitted by the form-factor of various structural models of bicelles, and the SASView software has been used [19]. The increased SANS signal in the small $q$ region for $\mathrm{CcO}$ in DDM clearly indicates the aggregation in the system. The power-law behavior of the scattering intensity close to $-2\left(I(q) \sim q^{-2}\right)$ corresponds well to so-called $2 \mathrm{D}$ or plate-like particles (one of the dimensions is much smaller than another two) which is the case of bicelles (see the sketch in Fig. 1). It should be noted that the model of core-shell bicelles, parallelepiped and core-shell sphere, could fit the experimental SANS data (Fig. 5, b).

The small-angle neutron scattering from aqueous solutions of bicelles and bicelles with $\mathrm{CcO}$ was measured at different volume fractions of $\mathrm{D}_{2} \mathrm{O}$ in the aqueous medium $\left(\mathrm{H}_{2} \mathrm{O} / \mathrm{D}_{2} \mathrm{O}\right)$. SANS contrast varia- tion experiments from an individual component (bicelles in aqueous solutions), as well as the complex system, $\mathrm{CcO}$ incorporated into the bicelles, were performed to get the mean scattering length density of pure bicelles and the complex object in a solution. The experimental scattering curves for bicelles and the complex of $\mathrm{CcO}$ with bicelles in various ratios of $\mathrm{H}_{2} \mathrm{O}$ and $\mathrm{D}_{2} \mathrm{O}$ are shown in Fig. 6, $a$ and Fig. 6, $b$, respectively.

The forward scattering intensity is proportional to the square of the contrast (scattering length density (SLD) difference between buffer and particles), $I(0) \sim \triangle \rho^{2}$. Thus, the lowest value of $I(0)$ vs $\triangle \rho$ corresponds to the match point. For homogeneous particles, the scattering length densities of the solvent and particles coincide at the match point. To find out the match point and the mean sample density, we used the dependence of the square root of the mean scattering intensity on the $\mathrm{D}_{2} \mathrm{O}$ content. In this case, the linear dependence was observed (Fig. 7). Since the forward scattering intensity with good accuracy is not easy to obtain for all scattering contrasts, the integration of SANS data in $q$-interval $0.16-0.6 \mathrm{~nm}^{-1}$ was done, and this value quite well correlates with the forward scattering intensity which is necessary for the contrast variation analysis. The precision of the determined match point is rather poor $((0.14 \pm 0.07)$ $\left[\mathrm{D}_{2} \mathrm{O}\right]$ and $\left.(0.18 \pm 0.03)\left[\mathrm{D}_{2} \mathrm{O}\right]\right)$; however, the mean value for bicelles corresponds well to the scattering length density of lipids with the classical average $\mathrm{SLD}=0.15\left[\mathrm{D}_{2} \mathrm{O}\right]$. Such small difference of the ex-

ISSN 2071-0194. Ukr. J. Phys. 2020. Vol. 65, No. 8 

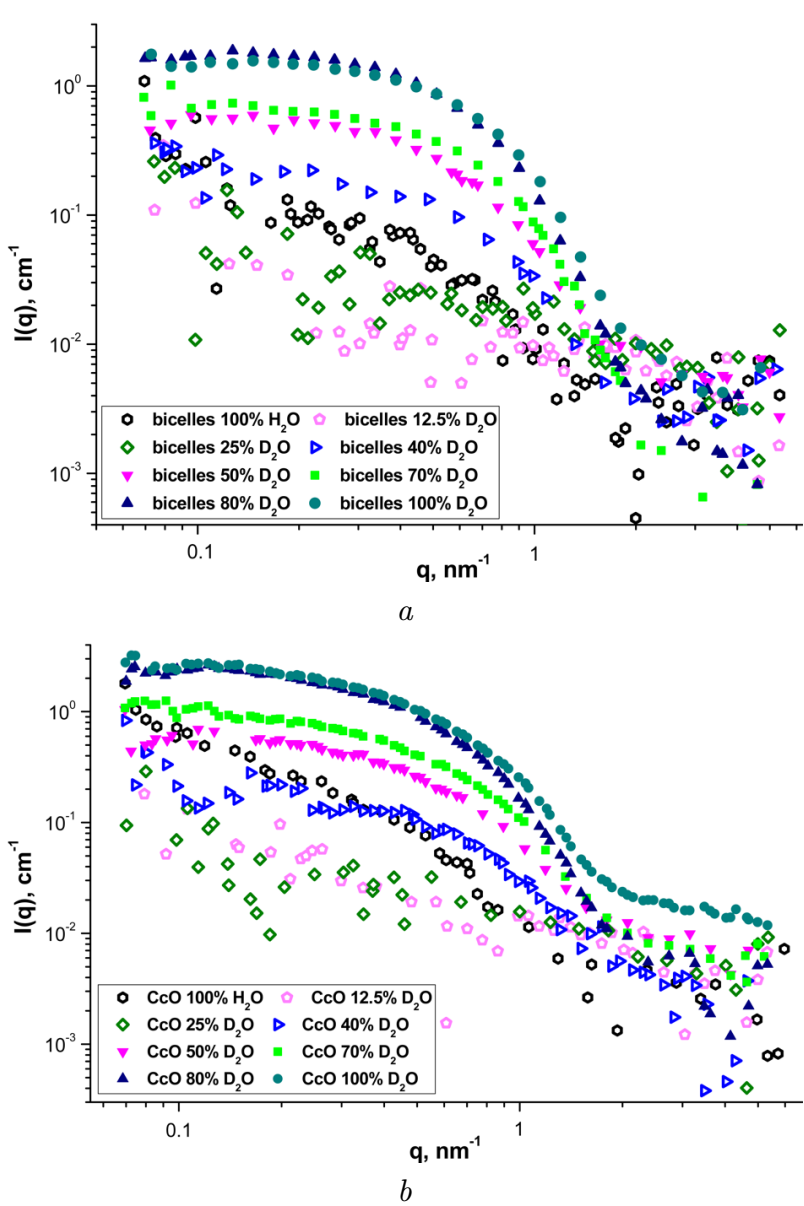

Fig. 6. SANS curves for bicelles in aqueous solutions $(a)$ and of $\mathrm{CcO}$ incorporated into bicelles $(b)$ at various amounts of $\mathrm{D}_{2} \mathrm{O}$

perimental SLD value for bicelles in comparison with the well-known SLD value for lipids could be also explained by the presence of some other components on the surface of bicelles in the solutions.

The next step was to estimate the volume fraction of the component per complex (bicelle with incorporated protein). The scattering length densities of the solvent mixtures, $\rho_{s}$, were calculated using the SLD of $\mathrm{H}_{2} \mathrm{O}$ and $\mathrm{D}_{2} \mathrm{O}$ values $\left(\rho_{\mathrm{H}_{2} \mathrm{O}}=-0.559 \times 10^{10} \mathrm{~cm}^{-2}\right.$, $\left.\rho_{\mathrm{D}_{2} \mathrm{O}}=6.34 \times 10^{10} \mathrm{~cm}^{-2}\right)$. We assume that we have just two components in our complex, namely lipids and protein. The calculation of the volume fraction, $\phi$, of $\mathrm{CcO}$ per bicelles $+\mathrm{CcO}$ complex from match points was done as follows:

$\phi=\frac{\mathrm{SLD}_{\text {mixture }}-\mathrm{SLD}_{\text {bicelles }}}{\mathrm{SLD}_{\text {protein }}-\mathrm{SLD}_{\text {bicelles }}}$,

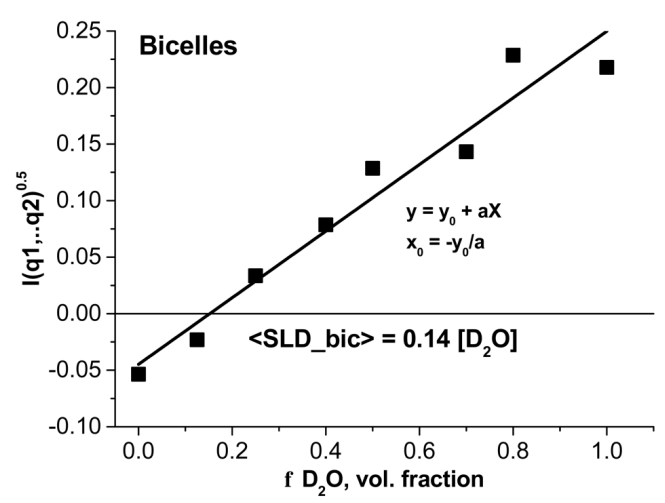

$a$

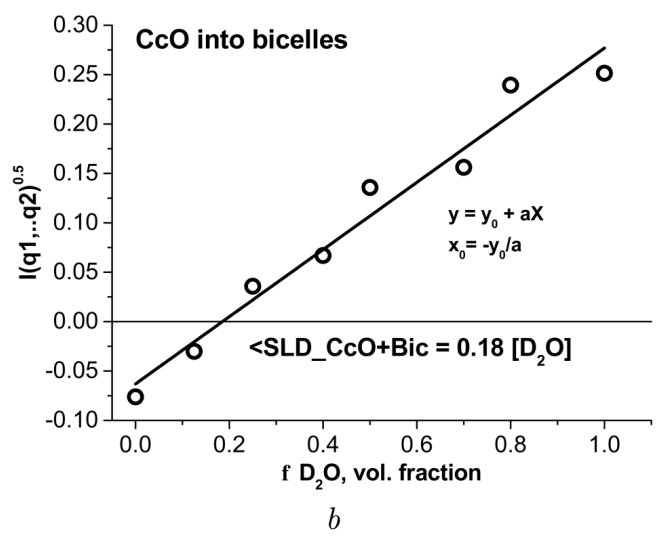

Fig. 7. Contrast variation for aqueous solutions of bicelles $(a)$, $\mathrm{CcO}$ with bicelles $(b)$, and corresponding match point values. The mean scattering intensity was determined for the $q$-interval $0.16-0.6 \mathrm{~nm}^{-1}$

where $\mathrm{SLD}_{\text {mixture }}$ is the match point for the complex of $\mathrm{CcO}$ with bicelles $(=0.18), \mathrm{SLD}_{\text {mixture }}=$ $=\phi \cdot \mathrm{SLD}_{\text {protein }}+(1-\phi) \cdot \mathrm{SLD}_{\text {bicelles }}, \mathrm{SLD}_{\text {bicelles }}$ is the match point for bicelles $(=0.14)$, and $\mathrm{SLD}_{\text {protein }}$ is the match point for protein $(=0.42$; tabular value for protein). Thus, according to the SANS contrast variation and above mentioned values, the volume fraction of $\mathrm{CcO}$ which is incorporated into the bicelle is about $\sim 0.14$. This value means that, on the average, the volume fraction of protein is $\phi=0.14$ from the whole volume of the complex object of bicelle with $\mathrm{CcO}\left(\phi=V_{\mathrm{CcO}} /\left(V_{\mathrm{CcO}}+V_{\text {bic }}\right)\right)$. Account for the average sizes of bicelle $\left(V_{\mathrm{bic}} \approx \pi d^{2} / 4 h=\right.$ $=1520 \mathrm{~nm}^{3}$, where the mean diameter of the disk $d=22 \mathrm{~nm}$, and the thickness of the disk $h=$ $=4 \mathrm{~nm}$ ), we could estimate the volume of protein per complex $V_{\mathrm{CcO}}=V_{\text {bic }} \phi /(1-\phi) \approx 240 \mathrm{~nm}^{3}$. Rubinson et al. (2012) calculated that the dimer of $\mathrm{CcO}$ has a volume of $494 \mathrm{~nm}^{3}$ [20]. Therefore, a 


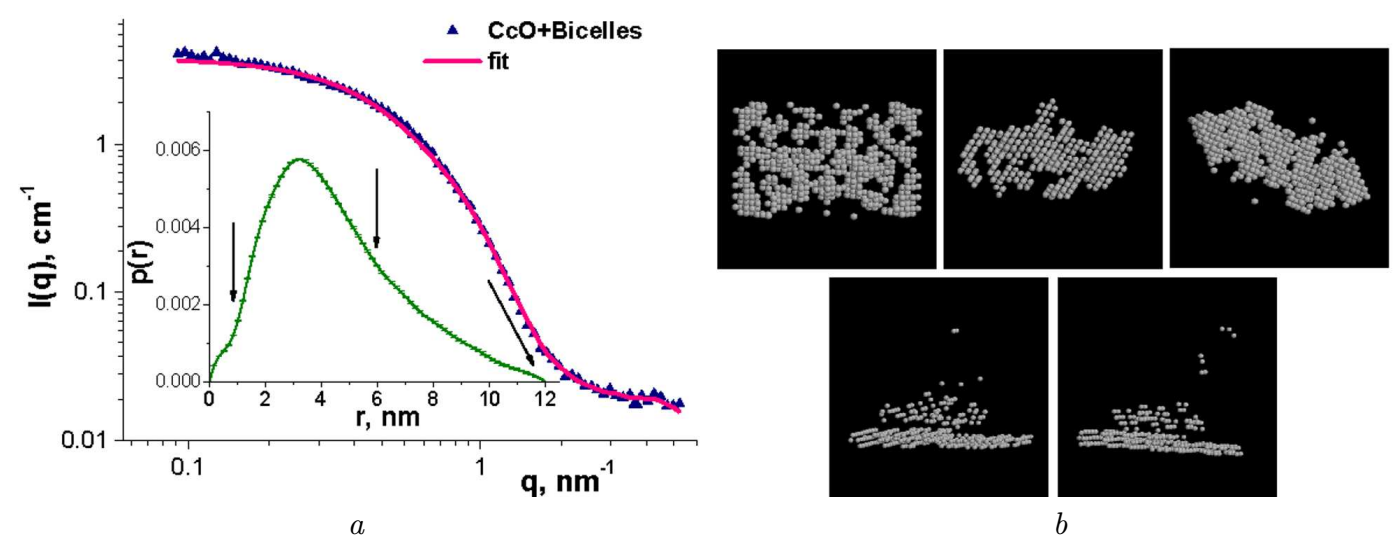

Fig. 8. SANS analysis of proteobicelles. SANS data for CcO into bicelles complexes $(a)$. The obtained pair distance distribution function is presented in the inset. Arrows show three characteristic sizes in such complexes. Modeling of the $\mathrm{CcO}$ aggregation state in bicelles $(b)$

volume of $240 \mathrm{~nm}^{3}$ correlates well with that of the monomeric enzyme. We also performed the ab initio modeling to obtain a more detailed view of bicelles and $\mathrm{CcO}$ incorporated into bicelles ("proteobicelles"). First, the GNOM program was used to make an indirect transformation of small-angle scattering data. As a result, the particle distance distribution function $P(r)$ was evaluated [21]. Then the $a b$ initio shape determination from small-angle neutron scattering data was done according to the well-known bead-modelling program DAMMIF [22]. In the bead modeling, a particle is represented as a collection of a large number of densely packed beads inside a search volume. Each bead belongs either to the particle or to the solvent. Starting from an arbitrary initial model, DAMMIF utilizes the simulated annealing to construct a compact interconnected model yielding a scattering pattern that fits the experimental data. The obtained 3D distributions of small beads are presented in Fig. 8, $b$, according to the DAMMIF fitting and analysis. As a result of the fitting of our SANS data together with the biochemical and biophysical characterization, we propose that $\mathrm{CcO}$ in bicelles is in a monomeric structure, and the model of $\mathrm{CcO}$ incorporated into bicelles is presented in Fig. 8.

\section{Conclusion}

In this work, the SANS measurements in combination with various biophysical and biochemical techniques have been used to investigate the structure and morphology of bicelles prepared from long- and shortchain phospholipids, as well as the mitochondrial mul- tisubunit electron-transfer complex with $\mathrm{CcO}$ incorporated into bicelles. The aggregation state of $\mathrm{CcO}$ isolated from bovine heart strongly depends on the amphiphilic environment, and the homogeneous population of either monomer or dimer is difficult to maintain. The scattering curves obtained for $\mathrm{CcO}$ incorporated into bicelles, dodecyl-maltoside, and TX100 micelles were analyzed. The volume fraction of protein per bicelle was estimated from SANS contrast variation experiments. Based on the analysis of SANS data along with the biochemical and biophysical characterization, we propose that $\mathrm{CcO}$ in bicelles forms a homogeneous monomeric structure, and bicelles can be used as a model membrane system in the investigation of highly hydrophobic proteins.

This work was supported by research grants from the Slovak Grant Agency VEGA (No.2/0009/17), Slovak Research and Development Agency (No. APVV-15-453) and SVK-JINR project No. 4744-4-18/20.

1. B. Kadenbach, J. Jaraush, R. Hartmann, P. Merle. Separation of mammalian cytochrome c oxidase into 13 polypeptides by a sodium dodecyl sulfate-gel electrophoretic procedure. Anal. Biochem. 129, 517 (1983).

2. M.K.F. Wikstrom. Proton pump coupled to cytochrome c oxidase in mitochondria. Nature 266, 271 (1977).

3. T. Tsukihara, H. Aoyama, E. Yamashita, T. Tomizaki, H. Yamaguchi, K. Shinzawa-Itoh, R. Nakashima, R. Yaono, and S. Yoshikawa. The whole structure of the 13-subunit oxidized cytochrome c oxidase at $2.8 \AA$. Science 272, 1136 (1996).

4. A. Musatov, J. Ortega-Lopez, N.C. Robinson. Detergentsolubilized bovine cytochrome c oxidase: Dimerization de- 
pends on the amphiphilic environment. Biochemistry 39 12996 (2000).

5. A. Musatov, N.C. Robinson. Cholate induces dimerization of detergent or phospholipid solubilized cytochrome c oxidase. Biochemistry 41, 4371 (2002).

6. A. Musatov, N.C. Robinson. Bound Cardiolipin is essential for cytochrome c oxidase proton translocation. Biochimie 105, 159 (2014).

7. A. Musatov, K. Siposova, M. Kubovcikova, V. Lysakova, R. Varhac. Functional and structural evaluation of bovine heart cytochrome c oxidase incorporated into bicelles. Biochimie 121, 21 (2016).

8. L. Melnikova, V.I. Petrenko, M.V. Garamus, L. Almasy, O.I. Ivankov, L.A. Bulavin, Z. Mitroova, P. Kopcansky. Effect of iron oxide loading on magnetoferritin structure in solution as revealed by SAXS and SANS. Colloids Surf. B 12382 (2014).

9. V.I. Petrenko, M.V. Avdeev, V.M. Garamus, L.A. Bulavin, P. Kopcansky. Impact of polyethylene glycol on aqueous micellar solutions of sodium oleate studied by small-angle neutron scattering. Colloid. Surf. A Physicochem. Eng. Asp. 480, 191 (2015).

10. L. Melnikova, V. I. Petrenko, M. V. Avdeev, O. I. Ivankov, L.A. Bulavin, V.M. Garamus, L. Almasy, Z. Mitroova, P. Kopcansky. SANS contrast variation study of magnetoferritin structure at various iron loading.J. Magn. Magn. Mater 377, 77 (2015).

11. M.V. Avdeev, V.L. Aksenov, Z. Gazova, L. Almasy, V.I. Petrenko, H. Gojzewski, A.V. Feoktystov, K. Siposova, A. Antosova, M. Timko, P. Kopcansky. On the determination of the helical structure parameters of amyloid protofilaments by small-angle neutron scattering and atomic force microscopy. J. Appl. Crystallogr. 46 (1), 224 (2013).

12. L.R. Fowler, S.H. Richardson, Y. Hatefi. A rapid method for the preparation of highly purified cytochrome oxidase. Biochim. Biophys. Acta 64, 170 (1962).

13. S.N. Mahapatro, N.C. Robinson. Effect of changing the detergent bound to bovine cytochrome c oxidase upon its individual electron-transfer steps. Biochemistry 29, 764 (1990).

14. P. Kesa, M. Bhide, V. Lysakova, A. Musatov. Subunit analysis of mitochondrial cytochrome c oxidase and cytochrome bc(1) by reversed-phase high-performance liquid chromatography. Anal. Biochem. 516, 6 (2017).

15. A.I. Kuklin, A. V Rogachev, D. V Soloviov, O.I. Ivankov, Y.S. Kovalev, P.K. Utrobin, S.A. Kutuzov, A.G. Soloviev, M.I. Rulev, V.I. Gordeliy. Neutronographic investigations of supramolecular structures on upgraded small-angle spectrometer YuMO. J. Phys. Conf. Ser., IOP Publ. 848 012010 (2017).

16. A.G. Soloviev, T.M. Solovjeva, O.I. Ivankov, D.V. Soloviov, A.V. Rogachev, A.I. Kuklin. SAS program for two-detector system: Seamless curve from both detectors. J. Phys. Conf. Ser. 848, 012020 (2017).
17. E.A. Kyzyma, A.A. Tomchuk, L.A. Bulavin, V.I. Petrenko, L. Almasy, M.V. Korobov, D.S. Volkov, I.V. Mikheev, I.V. Koshlan, N.A. Koshlan, P. Blàha, M.V. Avdeev, V.L. Aksenov. Structure and toxicity of aqueous fullerene $\mathrm{C}_{60}$ solutions. J. Surf. Invest.: X-Ray 9 (1), 1 (2015).

18. L.A. Bulavin, V.M. Garamus, T.V. Karmazina, E.N. Pivnenko. Measurements of structural and electrostatic parameters and surface tension of micelles of an ionic surfactant versus concentration, ionic strength of solution and temperature by small-angle neutron scattering. Colloid. Surf. A Physicochem. Eng. Asp. 131 (1-3) 137 (1998).

19. M. Doucet, M. Cho, J. Hie, A. Gervaise, J. Bakker, W. Bouwman, P. Butler, K. Campbell, M. Gonzales, R. Heenan, A. Jackson, P. Juhas, S. King, P. Kienzle, J. Krzywon, A. Markvardsen, T. Nielsen, L. O’Driscoll, W. Potrzebowski, L.R. Ferraz, T. Richter, P. Rozycko, T. Snow, A. Washington. SasView Version 4.2, Zenodo, 10.5281/zenodo.1412041.

20. K.A. Rubinson, C. Pokalsky, S. Krueger, L.J. Prochaska. Structure determination of functional membrane proteins using small-angle neutron scattering (SANS) with small, mixed-lipid liposomes: native beef heart mitochondrial cytochrome c oxidase forms dimers. Protein J. 1, 27 (2013).

21. D.I. Svergun. Determination of the regularization parameter in indirect-transform methods using perceptual criteria. J. Appl. Cryst. 25, 495 (1992).

22. D. Franke, D.I. Svergun. DAMMIF, a program for rapid $a b$ initio shape determination in small-angle scattering. J. Appl. Cryst. 42, 342 (2009).

Received 22.03.20

К. Шипошова, В.І. Петренко,

О.І. Іванъков, Л.А.Булавін, А. Мусатов

МАЛОКУТОВЕ РОЗСІЯННЯ НЕЙТРОНІВ

У ДОСЛІДЖЕННІ БІЦЕЛ ТА ПРОТЕОБІЦЕЛ

3 ІНКОРПОРОВАНОЮ МІТОХОНДРЕАЛЬНОЮ

ЦИТОХРОМОКСИДАЗОЮ

$\mathrm{P}$ е $з$ ю м е

За допомогою малокутового розсіяння нейтронів (MKPH), варіації контрасту в МКРН та різних біофізичних і біохімічних методів були виконані структурні дослідження модельних мембранних систем, біцел, та агрегаційний стан ізольованої та очищеної з бичачого серця цитохромоксидази в біцелах. Було отримано, що середня довжина біцел, які синтезовано за допомогою довголанцюгового 1,2-дімеристоіл-sn-гліцеро-3-фосфохоліну та коротколанцюгового 1,2-дігексаноіл-sn-гліцеро-3-фосфохоліну, становила 22 нм, а товщина дорівнювала 4 нм. Ензим в біцелах залишався активним та структурно незмінним. Розрахований об'єм протеїну в біцелі $\sim 240 \mathrm{нм}^{3}$ добре узгоджується з мономерною формою цитохромоксидази. Моделювання з перших принципів підтвердило експериментальні дані про те, що цитохромоксидаза в біцелах є гомогенною, і що лише мономерні комплекси інкорпоровані в біцели. 